\title{
64 什器を有する室内の照度分布について
}

\author{
一什器の高さによる比較一
}

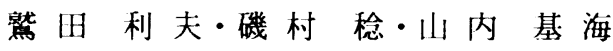 \\ （日本大学生産工学部）
}

先に筆者らは、作業面における照度分布を什器の反 射率によって比較した。(1)そこで今回は、什器の高さ を変えて作業面の全照度分布を測定し、什器の高さが 作業面の全照度分布に及ぼす影響を検討したので報告 する。

図1は、実験に用いた縮尺モデル窒(一般的な事務室 を想定した）で、間口、燠行き其50（cm)、高さ25（cm） のものである。光䃇は、均等拡散性の配光に近似した 一边が 15 ( $\mathrm{cm}$ )の正方形の面光源で、これを天井面と 同一平面亡なるように天井面の中心位置に取り付けた。 作業面の全照度測定に用いた受光器は、ホトダイオード と演算増幅器からなるもので、この受光器を作業面に 等間隔に 10 個埋め込み、作業面を移動することによ り、作業面における 100 点の全照度に比例する電压 を测定した。実験に用いた什器は、長さ15(cm)，幅 $4(\mathrm{c} \mathrm{m})$ で高さが h1 = $18(\mathrm{~cm}) 、 \mathrm{~h} 2=13.5(\mathrm{~cm})$ そし て $\mathrm{h} 3=9(\mathrm{~cm})$ の 3 種類とし、また什器の反射率は 70 (\%)及び5.6（\%)のものを使用した。この什器は、四 1 に示すように壁面1側より15（cm)離れたところで 壁面、4 密着した位置に取り付けた。また、縮尺モデ ル室の各面の反射率は、天井面が約50（\%)、4つの壁 面が共に約7 0 （\%)そして作業面が約 30 （\%)である

図 2 は、壁面、4より2.5（cm)離れたF1（図1）におけ る作業面の全照度分布を什器の高さにより比較した結 果の一例で、什器の反射涪が 70 （\%)と $5.6(\%)$ の場 合である。什器と壁面W1側における全照度分布は、什 器のない場合に比較して什器があると低くなり特に什 器の近傍では著しく低くなっており、什器の高さが高 くなるほど全照度に及ぼす什器の影響が大きくなつて いることがわかる。これは、什器の高さが高くなるほ ど光碩からの淔射光の遮られる割合が大きくなるため と考えられる。また、什器と壁面W3側における全照度 分布は、什器の反射率が70（\%)の場合には、什器の高 さによる影響はあまり見られていない。また、什器の 反射率が $5.6(\%)$ と低くなると什器の高さが低くな るほど全照度分布は高くなっており什器の高さが 18

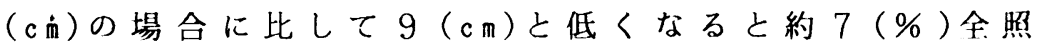
度が高くなっている。即ち、什器の高さによる影響は 約 7（\%)であることがわかる。今後は光源の取り付け 位置を天井而の中心より隅角へ移動させた場合似つい て行う予定である。

参考文献（1）村・山内：照明学会全国大会（昭61）５1

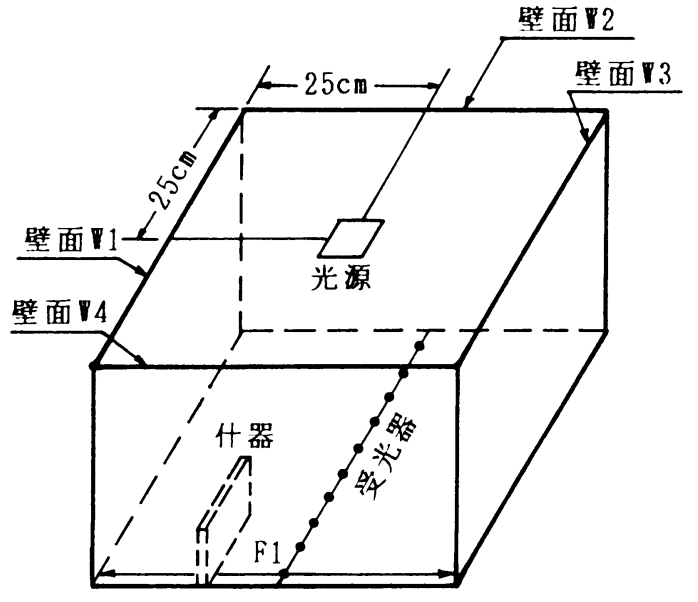

困 1 縮尺モデル公の概略
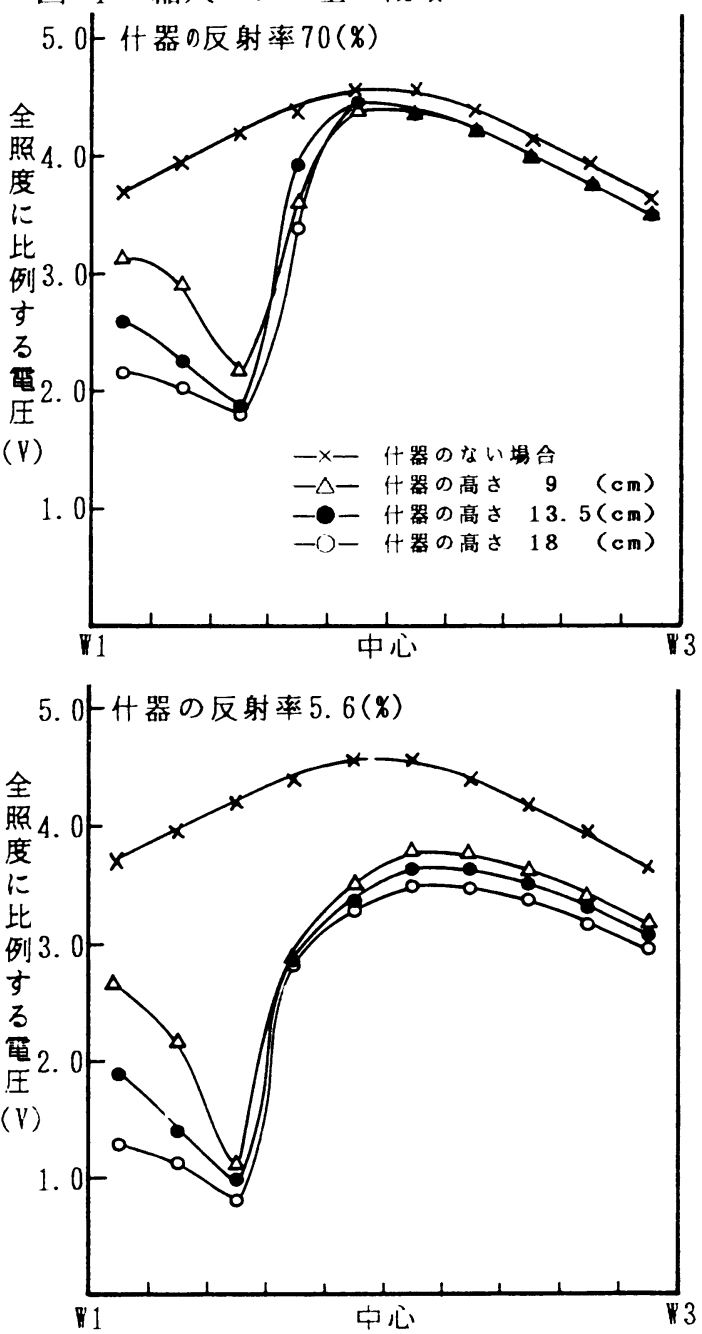

図 2 作業面の全照度分布

Il luminance distribution on a room surface with a obstruction(in comparison with the altitude of a obstruction), Toshio Washida, Minoru Isomura, Motomi Yamauchi 